\title{
Karnataka Tourism Satellite Accounts (Kar-TSA): A Necessity for the Tourism Industry
}

\author{
Mahesh Kumar*
}

\section{Abstract}

Tourism is being highlighted for its immense business opportunities with its close linkages to the transport and accommodation industry and a host of other sectors. The potential and performance of the tourism industry in the state of Karnataka, needs to be gauged in terms of its socio-economic magnitudes.

The present study focuses on the need for developing a Tourism Satellite Account (TSA) framework, which enables estimating or arriving at tourism activity impact on the state economy and its people, because tourism does not exist as a distinct sector, but happens across several sectors. The TSA framework separates out all tourism-related activity within gross state products (GSP).

World Tourism Organization developed this framework and so far, over 75 counties have either initiated or completed implementation of this framework. In 2006, India has published the first National Tourism Satellite Accounts. Efforts are being made to understand the need for adapting the sub-national level TSA for the state of Karnataka with discussions on the TSA conceptual framework and the present situation around the globe as well as in the sub-continent, followed by the findings and recommendations.

* Mahesh Kumar V, Guest Faculty, Department of Commerce, Bangalore University, Bangalore; mahesh.kumv@gmail.com 
Keywords: Measuring tourism impact; Tourism satellite accounts, Karnataka-TSA (Kar-TSA); Need for sub-national TSA.

\section{Introduction}

Tourism is the right vehicle to drive a country or a state like Karnataka on the path of economic growth. Furthermore, this sector has witnessed an upsurge in the recent years, where both visitors and producers have received rich dividends, and it is also a major source of employment generation. But tourism is not a priority area for business as well as policy decision makers, because they are not provided with the actual picture of its socio-economic benefits on the state and its people (stakeholders).

The forward and backward linkages of tourism with a host of others sectors in the economy, has made it so difficult for the national or sub-national (state) governments to estimate the economic significance of tourism. This sector has gained its industrial status recently in 1988 and is not recognized or accounted either in the system of state accounts or tables separately.

'TOURISM' is characterized by the nature of the final purchases of goods and services bought (Beynon et al, 2009), and tourism consumption is fragmented across various sectors where quantification becomes difficult. Even though state collects various forms of statistical data, measurement is difficult because to measure the role of tourism in the economy which is already 'embedded/buried' within the overall system of state accounts, is not available in a manner that would be readily usable for analysis of this sector.

The present status of the economic impact of tourism in Karnataka, is calculated by revenues generated by the core industrial sector i.e., accommodation and transportation and various form of taxes collected and direct travel-related employment as well as on the basis of various forms of infrastructure developmental activities undertaken at various tourist destinations.

It is very difficult to say that the state of Karnataka accurately captures the impact of tourism-related output and estimates 
employment generated by visitor expenditures on the economy. Even if the state argues, it is difficult to accept the validity of the said estimation, because only tourism sale is used as a proxy to estimate the impact of tourism expenditures on the economy, which creates several problems. The concept of Satellite Accounts has been developed to specifically address this kind of quantification problems encountered by various sun-rise sectors like tourism.

\section{Review of Literature}

Tourism is unevenly "localized" in the national territory, from both the demand and supply perspectives, which generate additional demand at the different territorial levels, that needs to be measured using reliable and suitable tourism statistics for decision-making by public as well as private stakeholders, with a framework of coherence and compatibility with the national and regional statistics (TSA:RMF: 2008 Annex-7: Pp100). The International Recommendations for Tourism Statistics(IRTS), addresses the specific issues related to establishing tourism statistics, covering different geographical environments and the need for definitions and concepts to adjust to such new venues, particularly 'the usual environment', the definition of the different categories of visitors and the existence of different procedures to relate tourism statistics at other geographical levels with that of the national tourism statistics (IRTS 2008 Chapter 8.c 'meaning tourism at sub-national levels').

Aydin (2008) highlights the importance of developing TSA Framework of estimating tourism expenditure impact using Florida's economy as a case study and explains that it does not exist as a distinct sector, and that its expenditure happens among several sectors; it is difficult to identify its impact on the state economy. The TSA method separates out all tourism-related activity within Gross state products (GSP) and recommends a TSA incorporated into a regional I-O model, such as REMI and IMPLAN to accurately measure the full impact on the state economy (Aydin 2008). Jones and Munday (2010) explain that extensions of the TSA to a Regional scale are an opportunity to undertake consistent analysis of the tourism economy and its interconnection based 
upon high quality and computable data. They further explain the limitations in the TSA structures which needs to be resolved, before policy useful analysis can become the rule rather than the exception and has tried to examine their usefulness to policy makers and, how far problems within the framework can be overcome in a practical manner (Jones \& Munday, 2010).

Apart from the above UNWTO conducted an International Conference on Measuring Tourism Economic Contribution at SubNational levels in 2008, in which the major focus was on countries that are now examining the potential to develop TSA at the regional level, even though this approach is being established at various national levels; it further highlighted the need to be aware of the different constraints that regions may face while preparing regional TSA's, and stressed the need of effective communication between agencies at the national and sub-national levels, to ensure the success of regional TSA and so on. (International Conference on Measuring Tourism Economic Contribution at Sub-National levels 29-31 October 2008, Malaga, Spain)

Worldwide, regional governments are developing tourism plans for expanding the tourism industry. These plans which are implemented will depend on the estimated net benefits on the local economies, by making use of different strategies. In such cases, a national level TSA may be of less relevance to the regional destination management organizations and local businesses. The extensive involvement of governments in tourism planning, infrastructure provision and marketing, at a state, regional or local level has led to the development of regional or sub-national TSA and conform that there are some challenges to the construction of regional TSA and also that there are benefits of estimating tourism's contribution to sub-regions of the national economy within the TSA Framework (Dwyer, Peter \& Qwyer, 2010).

National Council of Applied Economic Research (NCAER) conducted a pilot study on TSA for India in the form of various tables, which presented a disaggregated picture of various components of tourism in the country and also explained the method of arriving at estimates of the tourism sectors role in the economy and a brief introduction to the concepts, issues and the 
methodology and the basic findings of the first TSA for India were highlighted (TSA for India 2006).

\section{Need for the Study}

This study is a contemporary development in the field of measuring the impact of tourism activity on the national as well as sub-national levels, where only few countries which have developed during the $90^{\prime} \mathrm{s}$ and who have sound statistical data, have gone ahead and regionalized their TSA's. For a state like Karnataka, it is a new area of study altogether, so it is the apt time to improve the state-of-the-art tourism information system for the state of Karnataka, which will guide the public as well as private policy and business decision-makers as tools to invest as well as prioritize and develop tourism in the state and get maximum benefit/yield out of it, in various forms, and by adequately nurturing and stimulating tourism at the right time and right place, for improving socio-economic condition of the people and sustainable regional economic development. Considering these issues, it is felt that a study is required to be conducted, to highlight the necessity of a framework like TSA for the state.

\section{Objectives}

The objectives can be listed as follows:

- To understand the conceptual framework of Tourism Satellite Account.

- To examine the present situation around the world and in India.

- To examine the need for a sub-national level Tourism Satellite Account for the state of Karnataka.

With these broad objectives, this study tries to examine the problems of quantifying the economic impacts of the tourism industry through TSA framework as well as the need for choosing this framework for the state. 


\section{Methodology}

This study is contemporary in nature and is also a working paper for the author's doctoral work. Extensive secondary data (literature) were consulted and a detailed review as well as descriptive analysis was taken up, for which literature published from various national and international organizations. which were retrieved from online as well as printed forms (like Books, Journals, Conference proceedings, Reports and so on) were made use of. During the course of time, informal discussions in the form of unstructured interviews were conducted to understand the current situation of the state of information and knowledge, available in the field of Tourism Satellite Account and its uses, with the experts as well as officials in the Ministry of Tourism Government of India, Department of Tourism, Government of Karnataka, Karnataka State Tourism Development Corporation (KSDTC), National Sample Survey Office (NSSO), Bangalore, Tourism and Hospitality Entrepreneurs across the state (Travel Agents, Hoteliers, Restaurant and Resort People, Transport Operators and so on.

\section{Measuring the Economic Impacts of Tourism}

Total tourism impact is generally derived from three forms i.e., direct, indirect and induced which is generated by sales, income and employment throughout the state economy, by both foreign and native visitors to the various destinations across the state. The first form is called primary benefit from tourism and the latter two can be known as secondary benefits to the state which is enlisted in table 1 .

Criteria for evaluating economic impact methods: Methods for estimating tourism's economic impact are numerous and vary widely in their approach and output. It is important to judge the approaches by some formal criteria that permit the objective of evaluation of the quality of a model, because there are few independent measures of tourism's impact that can be used to assess an estimate effort. 
Table 1: Economic Benefit of Travel and Tourism

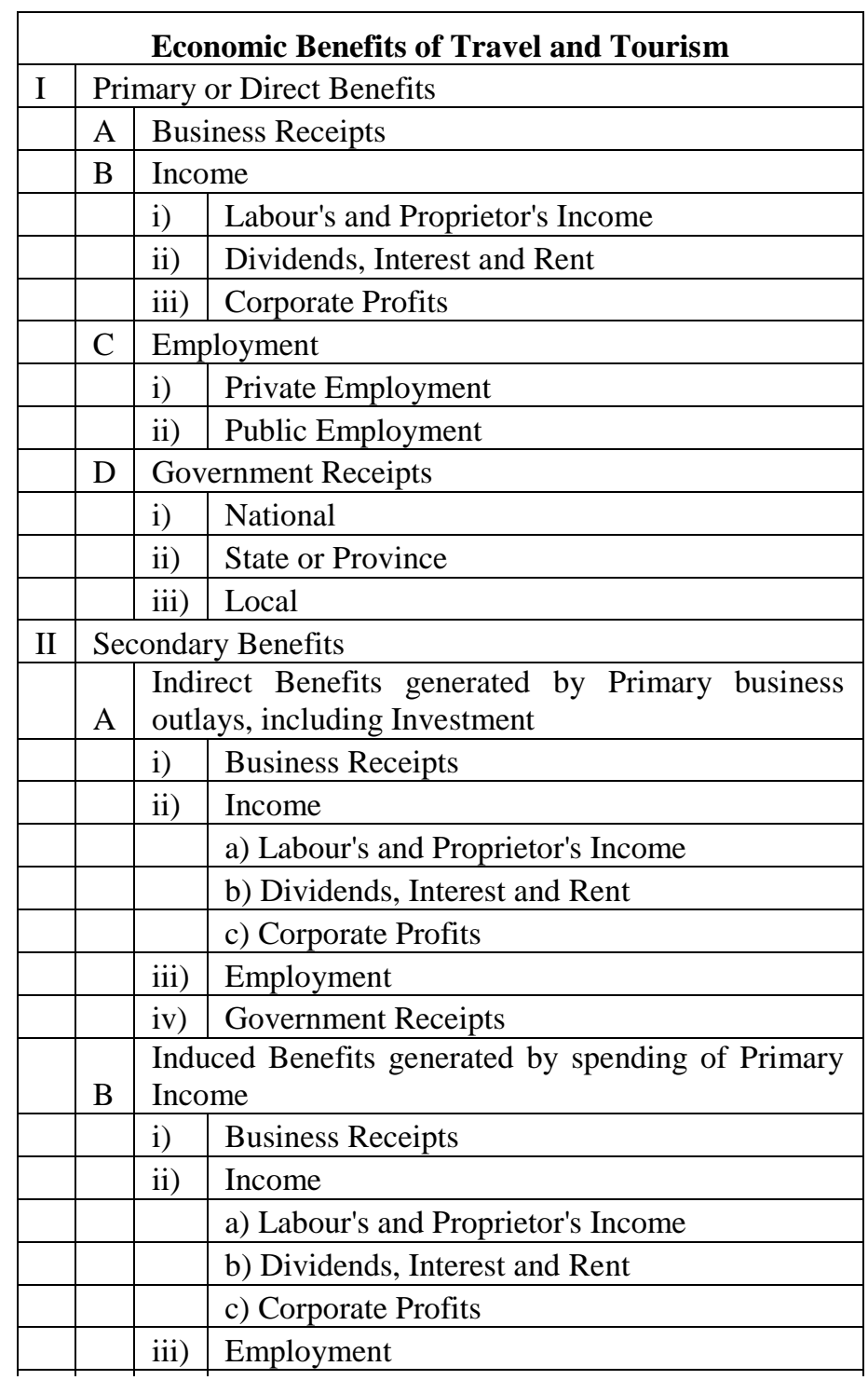

Source: (Frechtling: 1994, 361-363b)

As Aydin (2008) states the problems in estimating tourism economic impacts is that around the world many countries have worked hard to accurately estimate the contribution of tourism to their respective economies and accordingly arrange their policies. However, there are some serious problems and flaws in the basic 
traditional methods which were used for tourism measurement. A major problem has been the inconsistency of methods across regions/countries and/or time. Over the last three decades, countries and states have estimated tourism's economic impact with various measures and definitions.

Frechtling (1994a) identified eight different methodologies used to estimate tourism expenditures alone. This "pluralistic" approach measures the impact of tourism on a national as well as state level. It is also found that an economy prevents valid comparisons across nations/states as well as comparisons over time within the same economy.

As tourism is not generally treated as a separate industry, when measuring the economic impact of tourism, data for tourism is scattered/fragmented among various industries. As a result, collection of comprehensive and precise data on tourism expenditures becomes a herculean task, if not impossible.

Traditional methods focus on certain aspects of tourism's economic impact and thus fail to provide comprehensive information on tourism's contribution to an economy. Measures of tourism's contribution to an economy have generally been cantered on the gross expenditure (demand side). Expenditure-based measures do not reflect tourism's impact on regional employment or gross value added, or its induced effects on other industries, all of which have to do with the supply side and are of crucial importance for state economies (Edmunds, 1999).

The Tourism Satellite Accounts framework has emerged as a viable alternative to overcome the problems faced by adopting traditional methods to measure the tourism's economic impact in a comprehensive and consistent way.

\section{The Conceptual Framework of Tourism Satellite Account}

Tourism Satellite Account (TSA): "Satellite Account" is a concept developed by the United Nations to measure the size of economic sectors, that are not defined as industries in the system of national accounts (SNA). SNA is the conceptual framework that describes 
the international standards for measuring Gross Domestic Products (GDP).

The term "satellite" refers to the fact that a TSA is based on the input-output framework of a state/national economy. It is a subset of general input-output accounting. Tourism is an amalgam of industries such as transportation, accommodation, food and beverage ( $\mathrm{F}$ and $\mathrm{B}$ ) services, recreation and entertainment and travel. Therefore, it is not possible to identify a set of industries, add up their output/employment, and use the result to gauge the impact of tourism in a state or country. TSA addresses this kind of quantifying problem by weighing the output / employment of all tourism-related industries by the ratio of tourism expenditures to total expenditures for each industry (Egon, 2006).

TSAs are the outcome of the collaborative work of multiple national governments as well as international institutions, like the World Tourism Organization (WTO), the Organization for Economic Cooperation and Development (OECD), and the United Nations (UN), to create a more comprehensive and consistent measure of the economic impact of tourism. As early as 1983, the WTO called for the creation of "a uniform and comprehensive means of measurement [of tourism] and comparison with other sectors of the economy" (Smith \& Wilton 1997).

In 1994, the WTO started designing a TSA with the objective of presenting a comprehensive and integrated framework for estimating production, consumption, capital investment, employment, and other variables related to tourism activity. TSAs start with a solid definition of tourism and delineation of "core" tourism industry. As accepted by the UNWTO, TSAs define tourism as "activities of persons travelling to and staying in places outside their usual environment for not more than one consecutive year for leisure, business, and other purposes" (United Nations 1994).

TSAs' core tourism industry consists of five broad industries, they are: lodging, restaurants, entertainment, transportation, and retail. TSAs first measure tourism's impact on these industries. They then go beyond the core industry and measure tourism's indirect effect on the other industries. Thus, TSAs capture the impact of tourism 
on industries that benefit directly and/or indirectly from travel and tourism expenditures. A comprehensive list of industries has been mapped by NCAER, while constructing India's First TSA on which tourism's economic impact was measured in Table: 2

Table 2: Mapping of tourism related industries with commodities (items of expenditure)

\begin{tabular}{|c|c|c|}
\hline $\begin{array}{l}\text { Sl. } \\
\text { No }\end{array}$ & Tourism Related Industries & $\begin{array}{l}\text { Tourism Related Commodities (Items } \\
\text { of Expenditure) }\end{array}$ \\
\hline 1 & Accommodation Services & $\begin{array}{l}\text { Hotels, Private guest house, Tourist guest } \\
\text { house, Govt. guest house, Dharamshala, } \\
\text { Rented houses, Relatives, Others }\end{array}$ \\
\hline 2 & $\begin{array}{l}\text { Food and Beverage Serving } \\
\text { Services }\end{array}$ & $\begin{array}{l}\text { Food and Refreshment joints at Railway } \\
\text { station, bus stand, train, Hotels, Private } \\
\text { guest houses, Tourist guest houses, Govt. } \\
\text { guest houses, Dharamshala, Restaurants, } \\
\text { Cafeteria, Snack Bars, Lunch counters, } \\
\text { Refreshment stands, Canteens, Milk bars, } \\
\text { Bars \& other drinking places, Mela, Fair, } \\
\text { Picnic, Others }\end{array}$ \\
\hline 3 & \multicolumn{2}{|l|}{ Passenger Transport Services } \\
\hline & - Railway & Railway \\
\hline & $\begin{array}{l}\text { - Road (Buses and other } \\
\text { mechanized road } \\
\text { transport) }\end{array}$ & $\begin{array}{l}\text { Passenger transport by bus services and } \\
\text { other motor vehicles, Own Transport - } \\
\text { Two wheeler, Auto rickshaw / car / jeep / } \\
\text { bus / tractor and Others }\end{array}$ \\
\hline & $\begin{array}{l}\text { - Non Mechanized Road } \\
\text { Transport }\end{array}$ & $\begin{array}{l}\text { Passenger or freight transport via } \\
\text { hackney carriage, bullock carts, ekkas, } \\
\text { etc., Transport by animals and man } \\
\text { including rickshaw and cart pullers, } \\
\text { pushcart operators, palki bearers, doli } \\
\text { carriages, etc., Own Transport - Animal } \\
\text { driven transport, Own Transport } \\
\text { Rickshaw }\end{array}$ \\
\hline & - Water & Ship/boat \\
\hline & - Air & Air \\
\hline & $\begin{array}{l}\text { - Passenger Transport } \\
\text { Supporting Services }\end{array}$ & Other support services \\
\hline 4 & Transport Equipment Rental & Hired taxi / car / jeep / tractor \\
\hline 5 & Travel Agencies and similar & $\begin{array}{l}\text { Travel Agents, Tour Operators, Tourist } \\
\text { Guides }\end{array}$ \\
\hline 6 & $\begin{array}{l}\text { Other Recreational and } \\
\text { Entertainment Services }\end{array}$ & $\begin{array}{l}\text { Cinema, Night clubs, Theatres, } \\
\text { Conferences and Conventions, Other } \\
\text { Amusements }\end{array}$ \\
\hline
\end{tabular}




\begin{tabular}{|c|c|c|}
\hline 7 & Clothing and Garments & $\begin{array}{l}\text { Clothes (dhoti, sari, shirt, pajamas, ladies } \\
\text { suit, etc.), Chaddar, Dupatta, Shawl, } \\
\text { Lungi, Towel etc., Readymade garments, } \\
\text { Knitted garments, sweater, pullover, } \\
\text { cardigan, etc., Bedsheet, bed cover, } \\
\text { blanket, pillow, quits etc.., Knitting } \\
\text { wool, Others }\end{array}$ \\
\hline 8 & Processed Food & $\begin{array}{l}\text { Tea and coffee, Cold beverages and fruit } \\
\text { juice, Other beverages, Biscuits, salted } \\
\text { refreshments, prepared sweets, cake, } \\
\text { pastry, Pickle, Sauce, Jam, Jelly etc., } \\
\text { Other processed food }\end{array}$ \\
\hline 9 & Tobacco products & $\begin{array}{l}\text { Pan, Supari, Lime, Katha, Bidi, Cigratte, } \\
\text { Tobacco }\end{array}$ \\
\hline 10 & Alcohol & Beer, Toddy, Liquor, Other intoxicants \\
\hline 11 & $\begin{array}{l}\text { Travel Related Consumer } \\
\text { Goods }\end{array}$ & $\begin{array}{l}\text { Suitcase, trunk, hand bag, other travel } \\
\text { goods, Spectacles, pen, lock, umbrella, } \\
\text { Radio, walkman, torch, batteries etc., } \\
\text { Camera, cassettes, films etc. Others, } \\
\text { Photography, Video Cassette, Sports } \\
\text { items and Toys }\end{array}$ \\
\hline 12 & Footwear & $\begin{array}{l}\text { Leather footwear, Rubber footwear, } \\
\text { Others }\end{array}$ \\
\hline 13 & Toiletries & $\begin{array}{l}\text { Toilet soap, washing soap, washing } \\
\text { powder, hair oil etc., Tooth brush, tooth } \\
\text { paste, tooth powder, Body talcum, } \\
\text { powder, face cream, Shaving blades, } \\
\text { shaving stick, razor, shaving cream, } \\
\text { Other toiletries }\end{array}$ \\
\hline 14 & Gems and Jewellery & Gems \& Jewellery \\
\hline 15 & $\begin{array}{l}\text { Medicines and Health } \\
\text { Related items } \\
\end{array}$ & Medicines and Health Related items \\
\hline 16 & Printing and Publishing & $\begin{array}{l}\text { Book, magazines, Newspapers, Library } \\
\text { and other stationery }\end{array}$ \\
\hline
\end{tabular}

Source: India's Tourism Satellite Account 2002-03

A Tourism Satellite Account (TSA) is linked to a national/regional input-output table. It takes information from such a table based on the estimated share of tourism in the total sales of each industry. Fletcher (1989) terms input-output analysis as the most comprehensive method available for studying the impact of tourism. Input-output accounts, map out the full range of commodities that are produced by each industry in a state. An input-output table shows different industries within the 
national/state economy and how they are connected through their purchase and sales relationship. TSAs expand the detail for travel and tourism commodities provided in the input-output tables. They also provide detailed information on tourism-related employment and tourism generated taxes.

Structure of Tourism Satellite Accounts: The TSA is a set of 10 basic integrated tables in accordance with fundamental recommendations and a given aggregation of tourism-characteristic products and activities. The tables proposed in "TSA: the conceptual framework" document have been presented in their general sequence of compilation. However, in practice, the compilation may be incomplete, some tables (particularly those specific to certain forms of tourism) might be omitted and the formal sequence maintained. In Table 3: TEN TSA Framework Tables and their Coverage is listed

Table 3: List of TEN TSA Framework Table

\begin{tabular}{|c|l|}
\hline $\begin{array}{l}\text { List of } \\
\text { Tables }\end{array}$ & Coverage \\
\hline 1 & Inbound tourism consumption \\
\hline 2 & Domestic tourism consumption \\
\hline 3 & Outbound tourism consumption \\
\hline 4 & Internal tourism consumption \\
\hline 5 & Production accounts of tourism industries and other industries \\
\hline 6 & Domestic supply and internal tourism consumption \\
\hline 7 & Employment in the tourism industries \\
\hline 8 & Tourism gross fixed capital formation \\
\hline 9 & $\begin{array}{l}\text { Tourism collective consumption, by functions and levels of } \\
\text { government }\end{array}$ \\
\hline 10 & Non-monetary indicators \\
\hline
\end{tabular}

Source: World Tourism Organization

This makes TSA, an integrated set of these 10 tables. In its present form, it shows different aspects of tourism demand, supply, expenditure, income and production of tourism commodities and the inputs required by the industry in this process. Therefore, a significant methodological challenge in building the TSA is the availability, quantity and quality of data from existing sources. The 
magnitude of this challenge is a direct function of the strength of national statistical systems, where the need of a TSA is felt.

Benefits of TSA: Countries and states around the world have adopted the TSA or are in the process of implementing the standard, as a means to better understand the size and the make-up of travel and tourism in their jurisdiction. The fundamental reason behind this increased interest is that the TSA enables policy makers as well as strategic planners, to quantify and track the effects of travel and tourism on various sectors of the economy. The TSA is a powerful tool, as it shows the economic effects of travel and tourism in a way that is incomparable to the other sectors. It also reveals the strengths and weaknesses of the travel and tourism economy by answering questions such as:

- How much of each travel and tourism Rupee or dollar is retained in the state economy?

- How does the state government's support of tourism comparable to the tax revenues generated by the travel and tourism industry?

- Has travel and tourism been a source of economic growth?

- What are the effects of travel and tourism on other industrial sectors?

- How does travel and tourism rank compared to the other industries?

- How much tourism related jobs exist in an economy and what are the resulting wages and salaries?

- What contribution does tourism make to other industry sectors?

Over the past few years, WTTC has endeavoured to produce the most comprehensive TSA provided for within the UNWTO Conceptual Framework by developing the narrow concept of the Travel \& Tourism Industry in addition to the broader concept of the Travel \& Tourism Economy, and in doing so, has generated a number of benefits available to the government and industry worldwide. 


\section{Full implementation of a TSA can help governments understand:}

- the economic dynamics of tourism well beyond the traditional scope of expenditure research and production by the travel service sector;

- the relationship between tourism and the crucially important durable sector of the economy;

- the relationship between tourism and government spending, to help establish a clear linkage between tourism results and tourism support;

- the balance of payments arising from the comprehensive flow of tourism goods and services necessary to make tourism possible and, in the process, discovery of hidden trade surpluses or deficits;

- the relationship between tourism and capital investment to assist in long-term planning for infrastructure, resort development, promotion, etc;

- the difference between the immediate impact of tourism 'industry' GDP and employment, and the broader impact of tourism 'economy' GDP and employment, which can facilitate their policy analysis and decision-making;

- The interplay between a tangible, but unsatisfactory, supply-side perspective of employment generated by characteristic activities and the more theoretical, but accurate, perspective of demand-side generated employment.

\section{Full implementation of the TSA can help the industry to understand:}

- A wealth of customer and consumer information on tourism-related purchases (both domestic and international, imported or exported, services, durables, or non-durables, and purchases made before, during and after a trip) that has never been available before; 
- The full tourism product service chain and the government's ability to deliver quality and timely service to visitors;

- The history and forecast for public works that have benefited/will benefit visitors and travel companies, in order to capitalize on public sector intentions and priorities for growth;

- The opportunities for domestic production and for negotiating incentives from the public sector to aid in the growth of businesses, which help alleviate trade balance issues;

- The critical dual-perspective employment information that will allow industry to plan their human resource requirements and develop new and innovative ways to attract retain and grow their workforce. (WTTC 2008)

- Beyond these strategic benefits, the TSA provides a credible basis for communicating the significance of the travel and tourism sector to the media, legislators, and the public. The detail and the credibility of the accounts help to position travel and tourism within the economic development priorities.

\section{TSA development around the world}

Several countries have developed and disseminated their work on TSA. The briefly reviewed history of TSA suggests that, around 75 countries fall in the following categories with full or close-to full reporting on national TSA made by national, governmental or government-affiliated non-profit organizations.

- Countries with an established TSA

- Countries expecting that the implementation of their TSA will be highly developed in a year or two

- Countries that have recently developed relevant macroeconomic studies on the economic importance of tourism 
We should be aware that the number mentioned does not intend to be exhaustive and therefore could be enlarged to more than the 75 countries (SNA 2008, Hara 2008 and WTO 2010)

At the sub-national level, only few economies have initiated the work on regional / state level TSA which includes work in progress on National TSA or Regional TSA and the efforts made by the national / regional governments or those commissioned by outside profit organizations Like in Alaska, Florida, Louisiana, New Jersey, North Carolina (US), Crech, Denmark, Germany, Ireland, Italy, Japan, Macao, PR of China, Namibia, Poland, Portugal, Wales (UK), Spain, Thailand, United Kingdom (Hara 2008)

\section{TSA Development in India}

As the Tourism Satellite Account (TSA) is an accounting framework adopted by the United Nations and designed to measure goods and services associated with tourism, according to the international standards, concepts, classifications and definitions. To an extent, tourism is an economic phenomenon and many aspects of it are already embedded in the national accounts. The objective of developing India's first Tourism Satellite Account was to bring together the information by essentially reorganizing the national accounts and supplementing them with additional concepts and data and thus to develop relatively credible quantification of different aspects of tourism and identify important purposes that can be addressed by the TSA like to

- Provide a coherent and credible set of tourism accounts that can also be compared internationally across countries

- Develop quantitative estimates of value-added tourism and thus, analyze the importance of tourism in the economy

- Identify employment generation in tourism industries and the role tourism plays in job creation for different types of workers

- Offer a framework for developing impact models of tourism on economic activity and employment by identifying 
relationships between tourism industries and the rest of the economy

- Identify capital base of tourism industries

- Measure productivity within the tourism industry and compare it with the other industries.

As citied earlier, India is also one of the countries where TSA work has been extensively taken up by the national government to assess the socio-economic impact of tourism on the economy and its people. In 2006, it developed and disseminated its first TSA for the year 2002-03.

\section{A journey of five years in developing first TSA for India}

In 2001, a Feasibility Study was conducted for Developing TSA for India and the findings were summarized as below:

\section{Domestic Household Tourism}

- No current data on expenditure patterns,

- No data on Same-day Visitors

\section{Business Travel}

- No data source identifiable for corporate travel(both public and private)

- Central government data available only for total travel expenditure, no breakdown

- State government data may or may not be available

\section{International: Small Sample plus desegregation}

NCAER in 2002 conducted a Domestic Tourism Survey in two rounds i.e., Household survey in rural as well as urban areas and covered over 4, 00,000 households from 221 districts and 666 towns; the reference period was from January 2002 to December 2002

From January 2003 to December 2003, an International Passenger Survey - HICS was conducted, where 18,000 Foreign Nationals, 10,000 NRI and 2,000 Transit Passengers were interviewed. 
It was followed by the constitution of an Advisory Committee comprising of the Secretary, Ministry of Tourism (MoT), Government of India (GoI) as Chairperson, Additional Director General, Central Statistical Organisation (CSO), Advisor (Tourism) Planning Commission (PC), Joint Secretary, Ministry of Tourism, (MoT), Representatives of National Council of Applied Economic Research (NCAER), Representative of Ministry of Labour (MoL), Representative of Reserve Bank of India (RBI), and Joint Director General, Market Research, Ministry of Tourism as Convenor.

Then Seven TSA Tables were generated as per WTO recommendations, which are as follows Table 1: Inbound tourism consumption by products, Table 2: Domestic tourism consumption by products and by purpose of travel, Table 3: Outbound tourism consumption by products, Table 4: Tourism consumption by products and forms of tourism, Table 5: Production Accounts of the tourism industries Tourism Industry Ratios, Table 6: Tourism Value Added, and Table 7: Employment in the tourism industries

This was followed by a detailed presentation and discussion on the results of the first Tourism Satellite Account for India, which was published in 2006. While developing TSA for India, the following steps were followed (Shukla, 2006)

Step 1: Domestic Tourism Survey Data was adjusted for the under/over estimation using the factors obtained using NSSO and CSO ratio for the year 1999-2000.

Step 2: Inbound, Domestic (Factor Adjusted) and Outbound tourism expenditure, which is at the purchasers' price were converted to factor cost using I/O 1998-99 Trade and Transport Margin to Output ratios.

Step 3: The Ratio hence obtained on the tourism expenditure for tourism specific and related industries to their respective value of output, (supply side) gives the tourism industry ratio.

Step 4: These ratios, applied on value added of these industries give the tourism value addition.

Step 5: As per WTO recommendation, total employment in Tourism specific industries forms the total tourism employment. 
For tourism characteristic industries, labour to output ratio was taken from the NSSO survey on 'Unorganised Services' and the ratios are applied on tourism output to get the employment. For tourism related industries, tourism industries ratios are applied on total employment of these industries to get tourism employment.

\section{Problems encountered while preparing TSA for India}

- Data in the domestic and international passenger survey on tourism related industries was found to be under reported as compared to that available from National Accounts Statistics(NAS) - (Private Final Consumption Expenditure).

- Disaggregated data on expenditure on Road transport i.e., Buses, Mechanized Vehicle and non-mechanized road transport was not available in NAS also.

- Data for some of the sectors such as recreation, entertainment services were not available directly. The input-output table was used to get the requisite data.

- Expenditure data on railway transport was also found to be under estimated, because of the under reporting of the trips sponsored by the employer (Panday, 2008).

- On Domestic Tourist Visit Data: As per international definition, domestic tourists staying with friends and relatives during the trip are also treated as tourists. In India, data on domestic tourists are collected every month from the states. In India since there is difficulty in getting information about the tourists staying with friends and relatives, they are excluded from the definition.

- As per the international recommendations, data have to be collected on 'Same Day Visitors'. But, in India, some of the important fairs and festivals as well as the Temples, have huge crowds consisting of both same day and overnight visitors. There is an urgent need to formulate some statistical guidelines for estimating the number of same day visitors in such fairs and festivals. 


\section{Some of the Recent Initiatives taken up for improving TSA in India}

Monthly estimates of Foreign Tourist Arrivals (FTA): Earlier the monthly estimates of FTA were prepared using the data from only 4 metro cities (having about $69 \%$ share in the total FTAs). Now, the estimate is based on the data of six cities (having about $80 \%$ share in the total FTAs). Efforts are on to further expand the coverage to 10 cities (having about 93\% shares in the total FTAs).

Revision of the Methodology for the calculation of Foreign Exchange Earnings (FEE) from Tourism: Since Reserve Bank of India (RBI) is the nodal agency for FEE from Tourism on a monthly basis, with time lag of one week, whereas RBI releases Quarterly figures of FEE with a time lag of one quarter.

An all India Domestic Survey was conducted during July 2008 to June 2009 to provide various profiles of domestic tourists such as: Demographic profile and geographical diversity, Purpose of Travel by various characteristics, Details of the trips such as mode, main destination, month of the trip, place of stay, etc. and Average expenditure on trips according to purpose of the trips, social groups, etc (Pandey, 2008)

In spite of the above efforts, the process has only been initiated for the second TSA of India corresponding to the period of July 2008 to June 2009 (Pandey, 2008).

\section{Adapting the TSA to the Sub-National (Regional) Perspective}

Adapting the TSA conceptual framework to the sub-national levels can contribute to strengthening the role of state and local tourism administrations in policy designing and action. Keeping this in mind, efforts are made by WTO to provide general guidelines on how to adapt to the state context and has been evaluated as a fundamental contribution to the process towards the improvement of economic analysis of tourism at the sub-national levels i.e., from data collection to accounting and economic modelling and to understand tourism as an economic sector better. There is 
increasing pressure for the measurement of the tourism activity in the state perspective; there are various reasons that have prompted serious discussions to adopt at the sub-national level (TSA: RMF 2008) are:

- Need a better and more integrated regional and local information in order to allocate and monitor/ control resources effectively because throughout the world, a certain degree of 'de-centralization of political power' and especially the 'decentralized management' of national resources in federal states, regions, municipalities, etc. has been observed.

- Since the nature of tourism activities is multifaceted, it can potentially benefit the rural areas, which have been overlooked so far, as the prevailing production model is concerned with those seeking to diversify.

- Within national territory, the tourism activity is unequally characterized and geographically distributed unequally from both the demand and supply standpoints of view, which increases the need for additional tourism information at the various territorial levels.

- The interest from tourism-related businesses is growing towards the interrelation of their activity with others and about its main determinants and seasonal cycles.

- By only upgrading quantitative references and measuring economic impacts at the sub-national levels, the allocation of resources in national as well as local economies can be achieved.

- The need for regional and local information, is a result of the growing 'informatization of society' which makes it possible to have regional as well as local statistics available for use within coherent and harmonized framework.

- The need to have up-to-date information at the state level as well as tourism being a strategic sector of regional development. 
There is a growing interest in TSAs at the state level. So far, several states or provinces like Alaska, Florida, Louisiana, New Jersey, North Carolina (US), Crech, Denmark, Eurostat, Germany, Ireland, Italy, Japan, Macao, PR of China, Namibia, Poland, Portugal, Wales (UK), Spain, Thailand, and The United Kingdom (Hara 2008) have either developed or started developing their own TSAs.

WTTC collaborated with the Kerala government to produce the first 'simulated' Tourism Satellite Account (TSA) for an Indian state. Kerala is also one of the first state or provincial governments in the world to quantify the far-reaching contribution of travel and tourism to economic growth and employment because of the implementation of this new accounting concept which was approved by the United Nations Statistical Commission.

The report estimated the performance of Kerala's travel and tourism and provided forecasts based on the most recent national and international data fed into econometric models, developed by WTTC's research partner, Oxford Economic Forecasting. It quantifies all aspects of travel and tourism demand, from personal consumption to business purchases, capital investment, government spending and exports. Then it translates that information into economic concepts of production, such as gross state product and employment, which was compared with the other industries and the economy as a whole, to provide credible statistical information that assisted in policy and business decision processes.

The report highlighted that travel and tourism is already one of the highest prioritized industries. Tourism demand growth in Kerala is the highest in the world and is projected to increase by 11.4 per cent per annum over the coming decade and it also made certain policy recommendations:

- Establish development authorities for selected destinations.

- Encourage greater market and product diversification.

- Promote coastal cruises, luxury houseboats, water sports, Ayurveda, Kerala's cuisine and traditional festivals: Reconstitute Kerala's policy-making system, Place high priority on education and training, Improve airline access. 
Even though, WTTC and the Kerala government produced the first 'simulated' Tourism Satellite Account (TSA), for an Indian state in 2003 itself, no progress has been observed from any other state to develop this, and there is no sign of initiation happening. In the recent past it is observed that Simulated Tourism Satellite Account (TSA) project for the Lisbon city has been launched by WTTC in 2007.

\section{Tourism Scenario in Karnataka}

The state of Karnataka was established in the year 1956, under the States Reorganisation Act. It was originally called the state of Mysore and later renamed as Karnataka in 1973. It is the eighth largest state in the Indian union and comprises of $5 \%$ of the national population. The state is the largest base for the IT / ITES sector and is also a major investment destination for various sectors such as biotechnology, aerospace, automobile, engineering, sericulture and floriculture, mining and renewable energy. Karnataka is also the primary gold producing centre in India and the third largest producer of steel in India.

The state enjoys some of the highest growth rates in terms of state GSDP and per capita income and contributes about $8 \%$ to the Indian GDP. Figure 1 provides the annual growth rates for GSDP and per capita income. It can be seen that the period 2004-05 to 2007-08 was a period of high growth. Subsequent growth trends were however affected by the global recession that started in 2007, that was especially due to the slowdown in IT / ITES exports. The state has also been one of the major recipients for Foreign Direct Investment (FDI) over the last decade. A key reason for this, has been the growth of the state capital of Bangalore as one of the most important global technology hubs. The state contributes around one third of the total IT / ITES exports from India, while Bangalore contributes to more than $90 \%$ of the state exports.

The state is promoted under the tagline "One state, many worlds" and is one of the top ten domestic tourism destinations in India and was ranked 5th in 2010. The state has various tourism assets such as beaches, hill stations, heritage monuments, national parks, wild 
life sanctuaries etc. Some of the major tourism destinations in Karnataka can be classified under the following tourism themes:

Adventure sports-white water rafting (Dandeli, Kemphole, Sitanadi, Netravati), rock climbing (Ramnagar near Bangalore, Badami), trekking (Shimoga, Chikmagalur, Hassan, Kodagu), angling (Cauvery fishing camp), aero sports (Hebbal in Bangalore) etc. Beaches- Mangalore, Karwar, Gokarna, Malpe etc

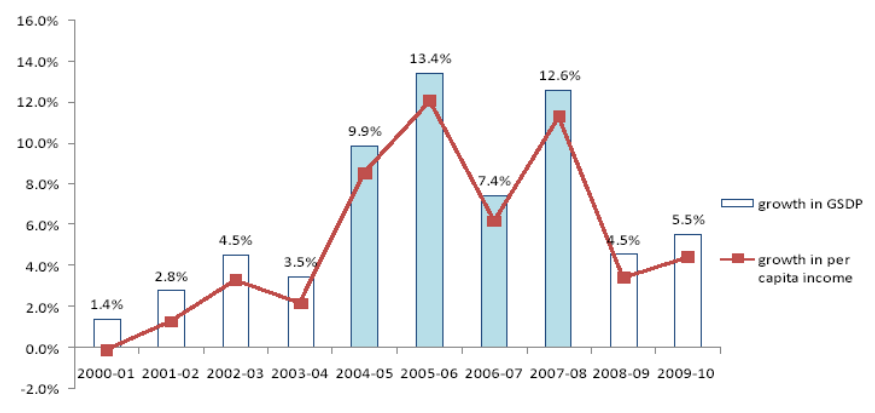

Fig. 1. Growth rates for Karnataka GSDP \& per capita income in INR over 2000-01 to 2009-10

Source: Directorate of Economics \& Statistics, Government of Karnataka

Heritage and culture- Hampi, Badami, Pattadakal, Aihole, Mysore palace, Srirangapatana etc

Hill stations and scenic spots- Coorg, Chickmagalur, Agumbe BR Hills, Nandi Hills, Jog falls etc

Wildlife and forests- National parks at Bandipur, BR Hills, Rajiv Gandhi National Park, Kudremukh National Park etc

City tourism \& MICE tourism- Bangalore and Mysore

At the same time, the state is mainly known for heritage and religious tourism, especially with reference to domestic tourists. Beach tourism is an emerging tourism product, which is expected to become more significant. MICE (Meetings, Incentives, Conventions and Exhibitions) based tourism is also expected to grow strongly in cities such as Bangalore and Mysore.

Karnataka attracted around 38.5 million tourists with around 38.2 million domestic tourists and 0.3 million international tourists in 
2010. The tourism figures for the last 5 years along with the associated growth rates are provided in the table 4 .

Table 4: International and Domestic Visitors to Karnataka

\begin{tabular}{|l|l|l|l|l|l|l|}
\hline Category & $\mathbf{2 0 0 5}$ & $\mathbf{2 0 0 6}$ & $\mathbf{2 0 0 7}$ & $\mathbf{2 0 0 8}$ & $\mathbf{2 0 0 9}$ & $\mathbf{2 0 1 0}$ \\
\hline International & 545,225 & 505,524 & 534,563 & 520,041 & 229,847 & 324,573 \\
\hline Growth rate & \multicolumn{7}{|l|}{$-7 \%$} & $6 \%$ & $-3 \%$ & $-56 \%$ & $41 \%$ \\
\hline CAGR & $9.1 \%$ over the 5 year period 2005-10 \\
\hline Domestic & $\begin{array}{l}24,698, \\
243\end{array}$ & $\begin{array}{l}36,195, \\
907\end{array}$ & $\begin{array}{l}37,825, \\
953\end{array}$ & $\begin{array}{l}37,010, \\
928\end{array}$ & $\begin{array}{l}32,729, \\
679\end{array}$ & $\begin{array}{l}38,202, \\
077\end{array}$ \\
\hline Growth rate & \multicolumn{7}{|l|}{$47 \%$} & $5 \%$ & $-2 \%$ & $-12 \%$ & $17 \%$ \\
\hline CAGR & $-9.9 \%$ over the 5 year period 2005-10' \\
\hline Total & $25,243,468$ & $36,701,431$ & $38,360,516$ & $37,530,969$ & $32,959,526$ & $38,526,650$ \\
\hline Growth rate & \multicolumn{7}{|l|}{$45 \%$} & $5 \%$ & $-12 \%$ & $17 \%$ \\
\hline CAGR & $8.80 \%$ over the 5 year period 2005-10 \\
\hline
\end{tabular}

Source: Department of Tourism, Karnataka

The above statistics indicate that domestic tourism is the primary drive for overall tourism growth in Karnataka. One of the major issues revealed by the statistics is the stagnation and decline of international tourist numbers as shown in Fig 2.

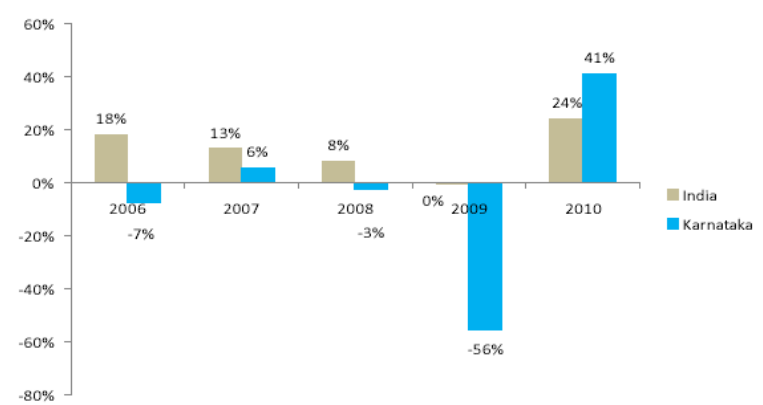

Fig. 2: Comparison of growth rates for international tourists- India and Karnataka Source: Directorate of Economics \& Statistics, Government of Karnataka

The overall CAGR - compound annual growth rate for the period 2005-10 is negative for international tourist numbers at $-9.9 \%$. 
While the quantum of the decline may be attributed to the massive fall seen in the year 2009, it is worth noting that the highest international tourist numbers over the period are seen in the year 2005.

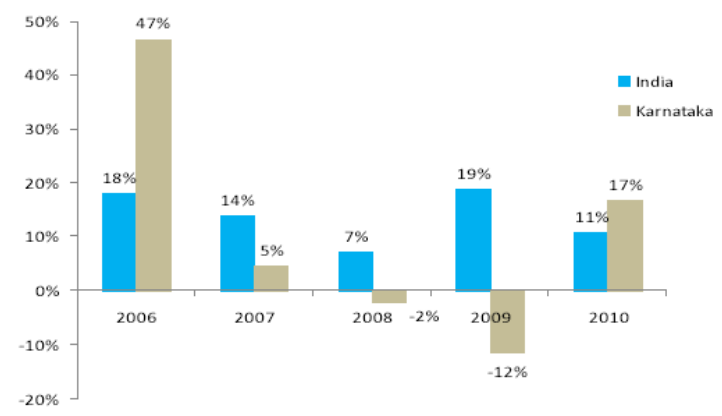

Fig. 3: Comparison of growth rates for domestic tourism- India and Karnataka Source: Directorate of Economics \& Statistics, Government of Karnataka

Figure 3 shows the overall contribution of Karnataka to the Indian tourism figures. While Karnataka remains one of the top ten contributors to domestic tourism (5th highest in 2010), the overall share for Tourism in India has come down over the period of 200510. The highest contribution is seen in 2006, while the lowest contribution is seen in 2009. In the case of international tourists, there is a clear downward trend, while a slight upswing can be seen in the year 2010 amongst the declining trend over the past 5 years.

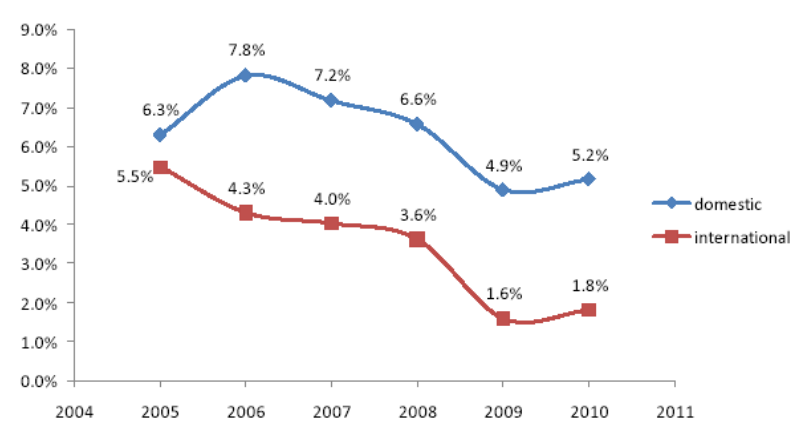

Fig. 4: Contribution of Karnataka to India tourist numbers- International and Domestic Source: Directorate of Economics \& Statistics, Government of Karnataka 


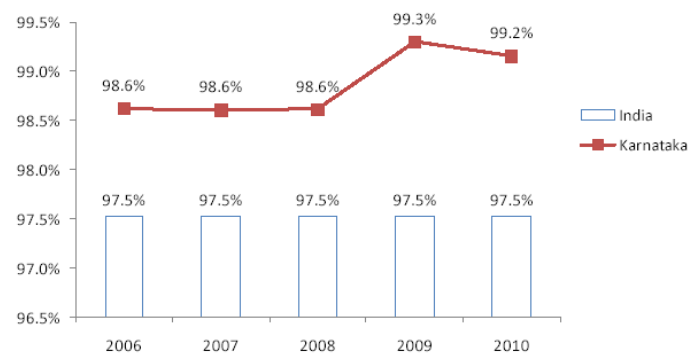

Fig. 5: Domestic Tourist Percentage for India and Karnataka

Source: Directorate of Economics \& Statistics, Government of Karnataka

\section{Revenue from Tourism in Karnataka}

There are no firm statistics with the Department of tourism, Government of Karnataka on earnings from tourism. But this sector earns a handful of foreign exchange, compared to the other products. These are generated through various sources in the form of direct and indirect incomes. National Tourism Development Council (NTDC) says that the foreign exchange earnings' share of the state of Karnataka would be nine percent of the total foreign exchange earnings earned by the country, and that comes to Rs. 1170.00 crores (2008). The revenue realised by public sector tourism organizations in Karnataka during the last few years are summarized in Table 5

Table 5: Revenue realised by public sector tourism organizations in Karnataka (in Lakhs)

\begin{tabular}{|l|r|r|r|r|r|r|}
\hline $\begin{array}{l}\text { Name of the } \\
\text { Organization }\end{array}$ & $2005-06$ & $2006-07$ & $2007-08$ & $2008-09$ & $2009-10$ & $2010-11$ \\
\hline $\begin{array}{l}\text { Directorate of } \\
\text { Tourism }\end{array}$ & 736.25 & 931.21 & 1314.39 & 3309.73 & 92.43 & 119.70 \\
\hline $\begin{array}{l}\text { Jungle } \\
\text { Lodges \& } \\
\text { Resorts Ltd }\end{array}$ & 1436.70 & 1927.41 & 2143.35 & 2597.68 & 2785.46 & 3298.74 \\
\hline $\begin{array}{l}\text { Karnataka } \\
\text { Tourism } \\
\begin{array}{l}\text { Development } \\
\text { Corporation }\end{array}\end{array}$ & 2098.17 & 2551.90 & 2819.89 & 4147.90 & 4020.02 & 5240.00 \\
\hline \begin{tabular}{l} 
Total \\
\hline
\end{tabular} & 4271.12 & 5410.52 & 6277.63 & 10055.3 & 6897.91 & 8658.44 \\
\hline
\end{tabular}

Source: Economic Survey 2010-11 and 2011-12, Department of Tourism, Government of Karnataka 
As cited earlier, the revenue generated by private enterprises is again not made available, as it happens across several sectors of the economy. This is not available for the planners in the manner in which it is required for decision making.

Table 6: Government allocation for tourism (Rs. In Crore)

\begin{tabular}{|l|l|l|}
\hline Year & $\begin{array}{l}\text { Infrastructure } \\
\text { Allocation }\end{array}$ & Marketing allocation \\
\hline $2007-08$ & 148 & 40 \\
\hline $2008-09$ & 250 & 144 \\
\hline $2009-10$ & 180 & 208 \\
\hline $2010-11$ & 204 & 132 \\
\hline $2011-12$ & 250 & - \\
\hline
\end{tabular}

Source: Economic Survey 2011-12, Department of Tourism, Karnataka

Further, the state outlay on tourism i.e., the state plan allocation for tourism is provided in Table 6. The budget of Karnataka in 20072008 is Rs. 148 Crores, in 2008-2009 is Rs.250 Crores, in 2009-10 - is Rs.180 Crores, in 2010-2011 is Rs. 204 Crores and for the year 2011 2012 is Rs.250 Crores only was allocated for tourism infrastructure development. It can be seen that the average annual state allocation is around Rs. 200 crore for the period shown, while the marketing allocation has seen a significant rise during the same period.

Table 7: Additional budget allocations in Karnataka for various other purposes

\begin{tabular}{|c|c|c|}
\hline Year & Purpose & $\begin{array}{r}\text { Amount } \\
\text { Allocated }\end{array}$ \\
\hline \multirow[t]{2}{*}{ 2008- 09} & $\begin{array}{l}\text { For maintenance and rejuvenation of existing tourist } \\
\text { facilities }\end{array}$ & Rs.40 crores \\
\hline & For Heritage Conservation & $\begin{array}{l}\text { Rs. } 12.50 \\
\text { crores }\end{array}$ \\
\hline \multirow[t]{3}{*}{$2009-10$} & $\begin{array}{l}\text { For development of Nandi Hills, } \\
\text { Kemmannagundi and Kodachadri hill stations }\end{array}$ & Rs. 10 crores \\
\hline & For Tagore beach in Karwar & Rs.5 Crores \\
\hline & $\begin{array}{l}\text { For renovation of Brindavan garden in } \\
\text { Krishnaraja Sagar }\end{array}$ & Rs. 5 Crores \\
\hline \multirow[t]{2}{*}{$2010-11$} & For development of theme park in Hampi & Rs. 50 crores \\
\hline & For developing roads and infrastructure at Sringeri & Rs. 5 crores \\
\hline \multirow[t]{3}{*}{$2011-12$} & For new infrastructure & Rs.50 crores \\
\hline & For development of theme park in Hampi & Rs.100 crores \\
\hline & For development of Hampi & Rs. 10 crores \\
\hline
\end{tabular}

Source: Finance Department Government of Karnataka 
Additional budget allocations for various other purposes which is provided in Table: 7 are:

- For maintenance and rejuvenation of existing tourist facilities,

- Heritage Conservation,

- Development of Nandi Hills, Kemmannagundi and Kodachadri hill stations,

- Development of Tagore beach in Karwar,

- Renovation of Brindavan Garden in Krishnaraja Sagar,

- Development of theme park in Hampi

- Developing roads and infrastructure at Sringeri

- New infrastructure and development of Hampi was allocated

This amount of allocation is no where sufficient for a state like Karnataka to cater to tourists with huge amount of competition from the other states and countries and the Government of Karnataka is not doing justice to the sector as with the other service sectors which continuously contribute to more than 50 percent to the State Domestic Product. They allocate budget for tourism in the end and that too a very small amount which when compared to the other sectors is very less. This happens, even though a huge amount of revenue is generated by this sector in the form tourist expenditure in tourism as well as related industries which is creating direct, indirect and induced impact in the state economy as well as amongst the people in the form of employment (skilled and unskilled).

\section{Findings}

With the detailed discussion, following findings were made, keeping in mind the current contexts and the need for developing sub-national TSA for Karnataka state and the present situation in India. 
- Due to non availability of valid information about tourist visits and their expenditure patterns and its socio-economic impact, the state is unable to cope up with the competition from the other states. This has pushed back, business decision makers to take various decisions regarding marketing, financial, human resources or infrastructure at the right time at the right place.

- Due to limited information on the tourism sector, in the recent global investors meet, the response was very low, when compared to other sectors, in spite of creating land bank and offering various forms of incentives to the entrepreneurs and MNCs to set up tourism and related infrastructure,

- In spite of potentiality, many existing entrepreneurs who were looking for opportunities for diversifying (horizontal) their present business enterprises have shown less interest in tourism and related industries, because of non availability of valid information about tourist movement in various destinations and the high gestation period when compared to the other sectors.

- While constructing national TSA, various problems have been encountered. The major one was providing incomplete information about tourists and their expenditure by the states, due to which the authorities have had to depend on estimates, which again has serious impact on the results, thus it is better to have a sub-national level TSA, so that while constructing the subsequent TSA table at the national level, it will be helpful at arriving at accurate results.

\section{Recommendations}

The above cited findings and associated problems can be addressed, if TSA at the sub-national level especially for a state like Karnataka is taken up and that is necessary for measuring the impact of tourism accurately. With this certain recommendations are made: 
- Need to develop appropriate strategies / approaches for the implementation of sub-national TSA for Karnataka. Even though in the literature Bottom-up and Top-down approach as well as Alternative approaches are available, it needs to be tested in this part of the country. It is apt to have a selfsustaining approach because implementing such an account for the first time involves huge amount of resources.

- It is better to identify the key user groups (i.e., people those who make use of TSA results) and those people who are supposed to provide information or datasets which is required while constructing TSA.

- Need to improve or modify the conceptual and methodological aspects of TSA to comprehensively compare with thr other states, nationally as well as internationally and with other sectors within the same economy.

- Need to identify required resources for the implementation of sub-national TSA like manpower, finance etc.

- It is better to update the existing Input-output tables with the latest demand and supply information, because while constructing TSA ratios as well as data to a large extent make use of I-O Tables.

- As citied earlier, the quantifying of tourism is based on demand i.e, tourist expenditure or purchases of the tourist across various sectors of the economy. Here, there arises a scope for conducting research on whether the factors influencing demand (Qualitative and Quantitative) will have any impact on the TSA basic tables.

- Need to develop a separate State Tourism Information (Statistical and TSA) Cell, which will collect and analyse the data and disseminate the same as per the needs of various user groups like state and central economics department, planning commission, central government tourism ministry, Home department, Civil Aviation, Railways, National Highway Authority, state and central industrial forums as well as associations like CII, FKCCI, FHRAI, TAAI, ICPB, IATO TAFI, KTF, etc. and investment forums. 
- Need to create awareness across various types of tourists like native visitors as well as domestic i.e., visitors from other states (rest of India) and International visitors to provide accurate information.

- Need to create awareness across various stakeholders, especially service providers about the uses of TSA and to form forums, to collect and pass the same to the TSA.

- Need to create awareness amongst various bureaucratic, administrative officers and politicians in the department of tourism and other departments about the need and importance of Tourism Satellite Accounts

\section{Conclusion}

All the above citied issues or problems can be addressed by contracting a comprehensive and internationally comparable accounts like sub-national tourism satellite accounts for Karnataka, which will enable direct comparison of the tourism sector with the other industries in an economy. The existence of a TSA has a much more significant role in practice. The central as well as the state government has to recognise that a TSA can serve as a tool for improving strategic management and planning for the tourism sector and enhance the effectiveness of Tourism and industrial policies. The policy relevance of a sub - national TSA has been described below.

- TSA can identify the type of tourists and their impacts on tourism expenditure for Karnataka. On this basis, one can establish appropriate marketing campaigns or strategies.

- Tourist expenditure patterns can reveal which commodity or industry, Karnataka needs to focus on, when there is an increase in demand by tourists, or more precisely a type of tourist. In this way, a sub - national TSA provides critical information for informing policy on investment and assessing public funding policies.

- Sub - National TSA is also relevant to labour force policies including education and training. 
- Sub - National TSA provides a continuous flow back and forth, between the supply and demand aspects of the tourism sector. It provides information about the interaction of tourism with the other industries in the economy. Sub National TSA, thus becomes an important tourism forecasting and modelling tool for impact analysis.

The State government will be the major user to provide the right ambience for the tourism sector. In response, elements of the private sector for which tourism activity is important and tourism industry associations should be able to rely on the TSA data to make their decisions. TSA can have considerable long term value and applications, particularly in supporting public policy making and by providing up-to-date and reliable information to all users of tourism economic data. Needless to say, though these efforts are just the beginning, and a lot more effort, time and resources will be needed to construct a full TSA for the state economy. It is observed that data collection is an expensive exercise and unfortunately, several gaps exists in our state-of the art statistical databases. But without a credible estimate and analysis of tourism sector in the state economy, tourism will continue to suffer from 'guesstimate' which will only hide the true potential of this sector in the state's economy. Both in terms of value added and employment, a credible analysis of tourism, based upon a sub-national TSA and data comparable nationally and internationally, is thus a necessity to move policy makers towards realizing the size and capacity of the tourism sector and to channelize resources to improve the performance of tourism in Karnataka.

\section{References}

Aydin, N. (2008). The need for tourism satellite accounts: A Florida case study. Applied Research in Economic Development, 5(3), 37-47.

Beynon, M., Munday, M., \& C. Jones, (2009). The embeddedness of tourism-related activity: A regional analysis of sectoral linkages. Urban Stud. 46(10), 2123-2141.

Dwyer, L., Peter, F., \& Dwyer, W. (2010). Tourism economics and policy; Volume 3 of Aspects of Tourism Texts, Channel View Publications. 
Edmunds, M. (1999). Tourism satellite account. Travel and Tourism Intelligence Occasional Studies, Travel and Tourism Analyst No. 3.

Egon, S. (2006). Tourism satellite accounts: A critical assessment. Journal of Travel Research, 45(1), 92-98.

Fletcher, J. E. (1989). Input-output analysis and tourism impact studies. Annals of Tourism Research, 16, 514 - 529.

Frechtling, D. C. (1994). Assessing the impact of travel and tourism measuring economic benefits, Inc. 361-363b, In J. R. B. Ritchie \& C. R. Goeldner (eds.). Travel, Tourism, and Hospitality Research: A Handbook for Managers and Researchers. New York: John Wiley and Sons

Hara, T. (2008). Quantitative tourism industry analysis: introduction to input-output, social accounting matrix modeling and tourism satellite accounts. Amsterdam, Elsevier Identification of tourism circuits across India: Interim Report-Karnataka 2012 Retrieved from http:// tourism.gov.in

Jones, C., \& Munday, M. (2010). Tourism satellite accounts for regions? A review of development issues and an alternative. Economic Systems Research, 22(4), 341-358.

Panday, R. N. (2008). Recent initiatives in tourism statistics and TSA in India. UNWTO Ninth Committee Meeting on Statistics and TSA, UNWTO HQ, Madrid.

Shukla, R. (2006). Tourism satellite account for India. UNWTO Committee on Statistics and Macroeconomic Analysis of Tourism, UNWTO HQ, Madrid.

Smith, S. L. J., \& Wilton, D. (1997). TSAS and the WTTC/WEFA methodology: Different satellites or different planets? Tourism Economics, 3 (3), 250. 